\title{
Bacterial and fungal community composition across the soil depth profiles in a fallow field
}

\author{
Daegeun Ko ${ }^{1}$, Gayoung Yoo ${ }^{2}$, Seong-Taek Yun ${ }^{3}$, Seong-Chun Jun ${ }^{4}$ and Haegeun Chung ${ }^{*}$
}

\begin{abstract}
Background: Soil microorganisms play key roles in nutrient cycling and are distributed throughout the soil profile. Currently, there is little information about the characteristics of the microbial communities along the soil depth because most studies focus on microorganisms inhabiting the soil surface. To better understand the functions and composition of microbial communities and the biogeochemical factors that shape them at different soil depths, we analyzed microbial activities and bacterial and fungal community composition in soils up to a $120 \mathrm{~cm}$ depth at a fallow field located in central Korea. To examine the vertical difference of microbial activities and community composition, $\beta$-1,4-glucosidase, cellobiohydrolase, $\beta$-1,4-xylosidase, $\beta$-1,4-N-acetylglucosaminidase, and acid phosphatase activities were analyzed and barcoded pyrosequencing of 165 rRNA genes (bacteria) and internal transcribed spacer region (fungi) was conducted.

Results: The activity of all the soil enzymes analyzed, along with soil $\mathrm{C}$ concentration, declined with soil depth. For example, acid phosphatase activity was 125.9 ( \pm 5.7 ( \pm 1 SE)), 30.9 ( \pm 0.9$), 15.7( \pm 0.6), 6.7( \pm 0.9)$, and $3.3( \pm 0.3)$ $\mathrm{nmol} \mathrm{g} \mathrm{g}^{-1} \mathrm{~h}^{-1}$ at $0-15,15-30,30-60,60-90$, and $90-120 \mathrm{~cm}$ soil depths, respectively. Among the bacterial groups, the abundance of Proteobacteria $(38.5,23.2,23.3,26.1$, and $17.5 \%$ at $0-15,15-30,30-60,60-90$, and $90-120 \mathrm{~cm}$ soil depths, respectively) and Firmicutes $(12.8,11.3,8.6,4.3$, and $0.4 \%$ at $0-15,15-30,30-60,60-90$, and 90-120 cm soil depths, respectively) decreased with soil depth. On the other hand, the abundance of Ascomycota (51.2, 48.6, 65.7, 46.1 , and $45.7 \%$ at $15,30,60,90$, and $120 \mathrm{~cm}$ depths, respectively), a dominant fungal group at this site, showed no clear trend along the soil profile.

Conclusions: Our results show that soil C availability can determine soil enzyme activity at different soil depths and that bacterial communities have a clear trend along the soil depth at this study site. These metagenomics studies, along with other studies on microbial functions, are expected to enhance our understanding on the complexity of soil microbial communities and their relationship with biogeochemical factors.
\end{abstract}

Keywords: Soil enzymes, Pyrosequencing, Microbial community composition, Diversity

\section{Background}

Soil microorganisms play an essential role in mediating nutrient cycling in the terrestrial ecosystem by decomposition of organic matters and transformation of inorganic compounds (Nannipieri et al. 2003, Xu et al. 2013, Sengupta and Dick 2015). Although soil microorganisms are present throughout the soil profile, our understanding of the composition of microbial communities at

\footnotetext{
* Correspondence: hchung@konkuk.ac.kr

'Department of Environmental Engineering, Konkuk University, Seoul 05029,

South Korea

Full list of author information is available at the end of the article
}

different soil depths is still insufficient. Majority of studies on soil microorganisms have focused on those inhabiting the topsoil ( $\sim 25 \mathrm{~cm}$ of the soil surface) where organic matter content and the abundance of soil microorganisms are high (Fierer et al. 2003, Eilers et al. 2012). Despite the fact that large numbers of microorganisms exist at deeper soil profiles, the characteristics of these communities and the distributions of microorganisms along the soil profiles remain less understood (Blume et al. 2002, Fierer et al. 2003, Eilers et al. 2012).

The microbial communities inhabiting subsurface soil layers are known to have a greater influence on the 
process of soil formation compared to those at the topsoil (Buss et al. 2005). In addition, subsurface soil microbial communities may play an important role in soil $\mathrm{C}$ sequestration since large amounts of organic $\mathrm{C}$ with long turnover times are stored in the subsurface horizons (Trumbore 2000, Fierer et al. 2005, Rumpel and Kogel-Knabner 2011). Therefore, determining the composition and characteristics of microbial communities at different soil depths will allow us to understand the important subsurface soil processes.

Significant differences in microbial community composition and function at different soil depths have been reported (Hansel et al. 2008, Will et al. 2010, Eilers et al. 2012). The diversity of microorganisms typically decreases with depth, whether diversity is determined by phospholipid fatty acid profiles (Fierer et al. 2003), DNA fingerprinting (LaMontagne et al. 2003, Agnelli et al. 2004, Goberna et al. 2005), 16S ribosomal RNA (rRNA) gene sequences (Will et al. 2010), or internal transcribed spacer (ITS) regions of the rRNA (Baldrian et al. 2012). This is due to changes in edaphic factors such as $\mathrm{pH}$, moisture contents, the quality and quantity of organic matters, and $\mathrm{O}_{2}$ concentrations throughout the soil depth profile. There is still little information on whether certain bacterial or fungal taxa are limited to specific soil depths and how that may relate to distinct microbial functions at different soil depths (Eilers et al. 2012).

Here, we analyzed the soil enzyme activities and used barcoded pyrosequencing to understand differences in the function and composition of soil bacterial and fungal communities at different soil depth in a fallow field located in central Korea. Our objective was to determine the differences in soil microbial community composition and function along the soil depth at this site.

\section{Methods}

\section{Site description and sampling}

The study site is a fallow field located in Eumsung-gun, North Chungcheong Province, in the central region of Korea (36 $\left.57^{\prime} 36.54^{\prime \prime} \mathrm{N} 127^{\circ} 27^{\prime} 59.80^{\prime \prime} \mathrm{E}\right)$. The site is situated on a small hillock area in the uppermost stream of Mihocheon, a primary tributary of the Geum River. The site is a fallow dry field surrounded by rice paddies. Within this site $(60 \mathrm{~m} \times 20 \mathrm{~m})$, eight soil samples were collected in September 2014 to a depth of $120 \mathrm{~cm}$ using a manual geoprobe. These samples were classified to five different depths: $0-15,15-30,30-60,60-90$, and 90$120 \mathrm{~cm}$. In our study, results of analyses of soils from one sampling point are reported because the soil enzyme activity at the other sampling points was too low for meaningful study on microbial activity and community composition to be conducted. Soil physicochemical properties including $\mathrm{pH}$, total $\mathrm{C}$ and $\mathrm{N}$ concentrations, and soil texture were determined.

\section{Soil enzyme activity}

To determine microbial community metabolism, fluorometric assays using methylumbelliferone (MUB)-linked substrates were performed. The activities of $\beta-1,4-$ glucosidase, cellobiohydrolase, $\beta$-1,4-xylosidase, $\beta-1,4$ $N$-acetylglucosaminidase, and acid phosphatase were analyzed which are extracellular enzymes that degrade cellulose, hemicellulose, chitin, and organic $\mathrm{P}$ substrate in soil (Saiya-Cork et al. 2002). Two grams of soil was placed in $125 \mathrm{ml}$ of sodium acetate buffer, and then, the slurry was transferred to a 96-well microplate that included eight analytical replicates of each enzyme assay. Plates for all five enzymes were incubated at the room temperature for $2 \mathrm{~h}$. Fluorescence was measured using a Synergy HT Multi-Mode Microplate Reader (BioTek Instruments Inc., Winooski, VT, USA), in which the excitation energy was set at $360 \mathrm{~nm}$ and emission was measured at $460 \mathrm{~nm}$. Enzyme activity was expressed as nmol 4-MUB g ${ }^{-1} \mathrm{~h}^{-1}$.

\section{DNA extraction, PCR, and pyrosequencing}

DNA was extracted from the soil samples using the FastDNA SPIN Kit (MP Biomedicals, OH, USA) following the manufacturer's instructions. The extracted DNA was amplified via PCR with the universal primers that target V1 to V3 hypervariable regions of the $16 \mathrm{~S}$ rRNA gene. The primers used to amplify the $16 \mathrm{~S}$ rRNA genes for bacteria were 27F (5'-GAGTTTGATCMTGGCTCAG-3') and 518R (5'-WTTACCGCGGCTGCTGG-3'). For fungal amplification, barcoded primers of ITS3F $\left(5^{\prime}\right.$-GCATCGATGAAGAACGCAGC- $\left.{ }^{\prime}\right)$ and ITS4R ( $5^{\prime}$-TCCTCCGCTTATTGATATGC-3') were used. PCR conditions were as follows: initial denaturation at $95{ }^{\circ} \mathrm{C}$ for $5 \mathrm{~min}, 30$ cycles of denaturation at $95{ }^{\circ} \mathrm{C}$ for $30 \mathrm{~s}$, primer annealing at $55{ }^{\circ} \mathrm{C}$ for $30 \mathrm{~s}$, extension at $72{ }^{\circ} \mathrm{C}$ for $30 \mathrm{~s}$, and a final elongation at $72{ }^{\circ} \mathrm{C}$ for $5 \mathrm{~min}$. The PCR products were purified using the QIAquick PCR purification kit (Qiagen, Valencia, CA, USA), and the non-target products were removed employing Ampure beads kit (Agencourt Bioscience, MA, USA). The quality and product size were analyzed on a Bioanalyzer 2100 (Agilent, Palo Alto, CA, USA) employing a DNA 7500 chip. Emulsion PCR was conducted on the mixed amplicons, and the sequencing was performed at Chunlab, Inc. (Seoul, Korea) using GS Junior Sequencing System (Roche, Branford, CT, USA) following the manufacturer's protocol.

\section{Pyrosequencing data analysis}

Pyrosequencing data were analyzed following the descriptions in previous studies (Chun et al. 2010, Hur et al. 2011, Kim et al. 2012a). Reads obtained were sorted according to unique barcodes of the PCR products. Potential chimera sequences were identified via the 
Bellerophone method (Huber et al. 2004) and subsequently removed. Each read was then taxonomically classified according to the EzTaxon-e database (http://ezbiocloud.net/taxonomy) (Kim et al. 2012b). Sample richness and diversity were determined via Chao1 estimation and Shannon diversity index at the 3\% distance. The phylogenetic distance between the microbial communities was estimated and visualized by the Fast UniFrac (Hamady et al. 2010) and principal coordinates analysis (PCoA). Shared operational taxonomic units (OTUs) were obtained by taxon exclusive-OR (XOR) analysis of CL community program (Chunlab Inc., Seoul, Korea), and OTUs between the samples were compared. Unweighted pair group method with arithmetic mean (UPGMA) dendrogram was constructed, and the similarity between the soil samples from different depths was estimated.

\section{Statistical analysis}

One-way analysis of variance (ANOVA) was performed to determine the effect of soil depths on each soil enzyme. Scheffe's post hoc test was used in the case of multiple comparisons to detect the mean differences among different groups. Significance for the statistical analysis was accepted at $\alpha=0.05$. In addition, to understand the relationship between the soil physicochemical properties and soil microbial characteristics including catabolic activities and dominant bacterial and fungal taxa, correlation analyses were performed. Both analyses were performed using SPSS 18.0 software (SPSS Inc., Chicago, IL, USA).

\section{Results}

Soil enzyme activity and physicochemical properties

The activity of five soil extracellular enzymes, acid phosphatase, $N$-acetyl-glucosaminidase, cellobiohydrolase, $\beta$ 1,4-glucosidase, and $\beta-1,4$-xylosidase, was highest at the $0-15 \mathrm{~cm}$ depth. Soil enzyme activity decreased with depth $(p<0.001)$, decreasing by one to two orders of magnitude from the topsoil to the soil at $90-120 \mathrm{~cm}$ depth, and this trend was observed for all five enzymes (Fig. 1). The soil was sandy loam, and soil chemical properties varied with depth (Table 1). More specifically, soil total $\mathrm{C}$ and $\mathrm{N}$ concentrations decreased with depth, and also, $\mathrm{C} / \mathrm{N}$ ratio decreased with depth. Soil $\mathrm{pH}$ and moisture content ranged from 5.56 to 6.06 and 16 to $19 \%$, respectively. As expected, soil enzyme activity was significantly correlated with soil physicochemical characteristics. For example, all five soil enzymes were positively correlated with total $\mathrm{C}$ and total $\mathrm{N}$ concentrations $(r>0.87, p<0.01)$. In addition, acid phosphatase, $N$-acetyl-glucosaminidase, cellobiohydrolase, and $\beta-1,4-$ glucosidase were positively correlated with soil $\mathrm{pH}$ $(r>0.52, p<0.05)$, and acid phosphatase, $N$-acetylglucosaminidase, and $\beta-1,4$-xylosidase with soil moisture content $(r>0.53, p<0.05)$.

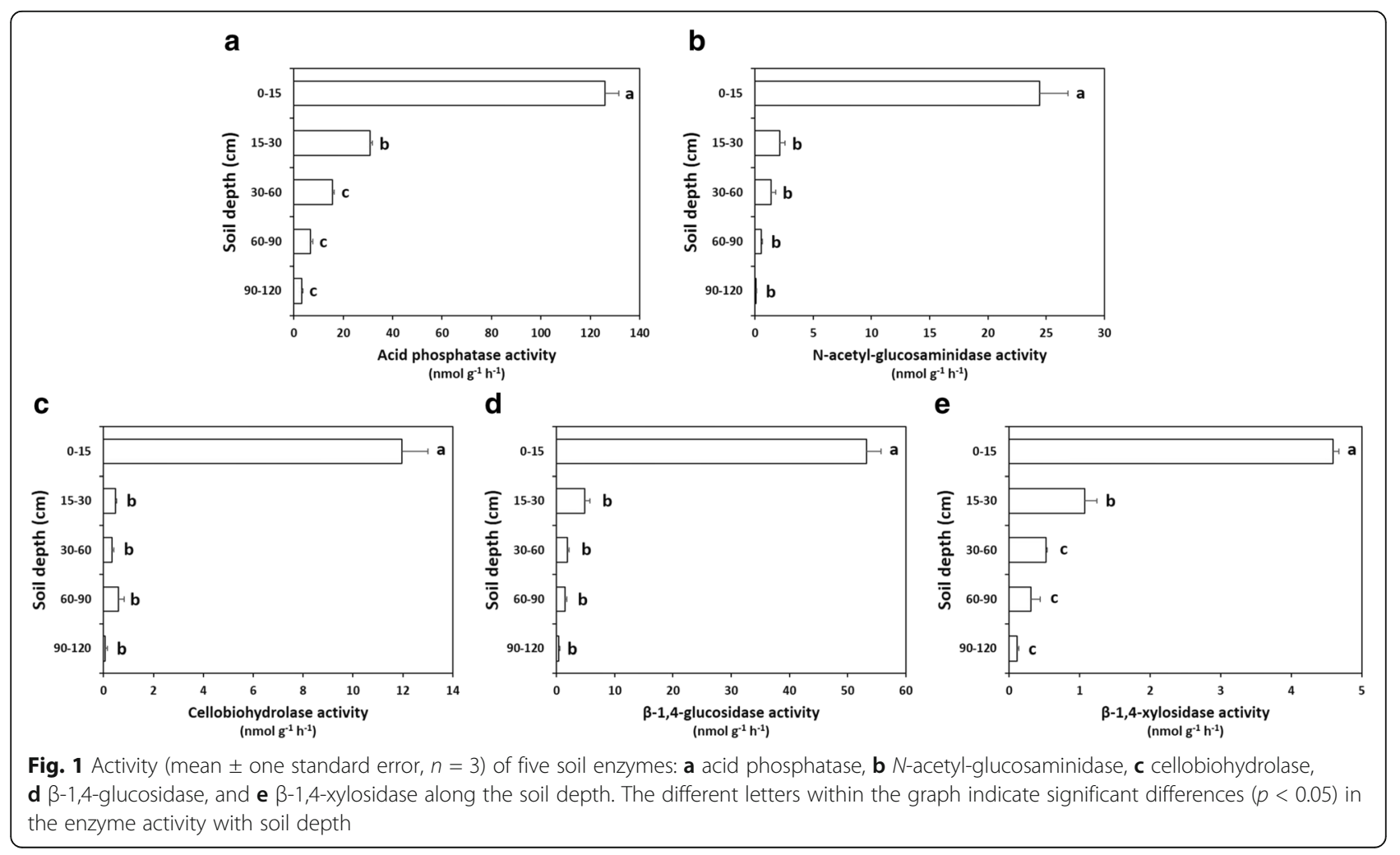


Table 1 Soil geochemical properties along the depth profiles

\begin{tabular}{llllll}
\hline Soil depth $(\mathrm{cm})$ & \multicolumn{5}{l}{ Soil chemical properties } \\
\cline { 2 - 6 } & $\mathrm{pH}$ & Total nitrogen $\left(\mathrm{g} \mathrm{N} \mathrm{kg}^{-1}\right.$ soil) & Total carbon $\left(\mathrm{g} \mathrm{C} \mathrm{kg}^{-1}\right.$ soil) & C/N ratio & Soil moisture content (\%) \\
\hline $0-15$ & 6.06 & 0.21 & 9.68 & 46.1 & 18.8 \\
$15-30$ & 5.56 & 0.16 & 3.92 & 24.5 & 18.6 \\
$30-60$ & 5.58 & 0.10 & 2.09 & 20.9 & 17.3 \\
$60-90$ & 5.92 & 0.10 & 2.45 & 24.5 & 16.5 \\
$90-120$ & 5.87 & 0.07 & 2.19 & 31.3 & 18.3 \\
\hline
\end{tabular}

\section{Soil microbial diversity}

After removing low-quality sequences, a total of 50,357 bacterial 16S rRNA sequences and 38,546 fungal ITS sequences were obtained. Across all samples, 11,032 bacterial OTUs and 2928 fungal OTUs were observed. To determine rarefaction curves, richness, and diversity of bacteria and fungi, OTUs were identified at $97 \%$ of genetic similarity. Analyses of rarefaction with OTU numbers for bacterial and fungal communities determined by richness estimators Ace and Chao1 revealed that 44 to $73 \%$ and 60 to $81 \%$ of the estimated taxonomic richness, respectively, were not saturated (Fig. 2). In addition, these were recovered by the sequencing effort especially in fungal communities at soil depths of 30-60 and 60$90 \mathrm{~cm}$. Therefore, in this study, the extent of taxonomic diversity at this genetic distance was not fully surveyed, but considerable fractions of both bacterial and fungal diversity within soil depths were assessed at the species level by the surveying effort (Fig. 2, Table 2).

Chaol richness estimates of bacterial communities at $3 \%$ genetic distance across all soil depth was $3400( \pm 837)$. It was highest at $60-90 \mathrm{~cm}$ depth and lowest at 90$120 \mathrm{~cm}$ depth (4810 vs. 2776). On the other hand, Chao1 estimates were $754( \pm 262)$ across all soil depths and it was highest at the 15-30 cm depth and lowest at the 90$120 \mathrm{~cm}$ depth (979 vs. 311). The richness was significantly higher in bacterial than in fungal communities. At the 3\% genetic dissimilarity level, the Shannon index ranged from
6.7 to 7.2 and 4.5 to 5.1 in bacterial and fungal communities, respectively. In bacterial communities, the Shannon index was highest at $60-90 \mathrm{~cm}$ depth, whereas it was highest at $15-30 \mathrm{~cm}$ depth in fungal communities (Table 2).

\section{Bacterial and fungal community composition along the soil depths}

The 50,357 sequences classified below the domain level were affiliated to 42 bacterial phyla. Across all samples, the abundance of bacterial phyla Acidobacteria, Proteobacteria, Actinobacteria, Chloroflexi, and Firmicutes was 28, 26, 11, 8, and 7\%, respectively, of all the sequences assigned to the domain Bacteria (Fig. 3a). The members of rare phyla, of which the abundance was less than $1 \%$ of all classified $16 \mathrm{~S}$ rRNA sequences, included Armatimonadetes, Elusimicrobia, OD1, MATCR, WS3, OP11, TM6, Chlorobi, Bacteria_uc, WS5, OP3, Deferribacteres, Fibrobacteres, GN02, BRC1, Tenericutes, Spirochaetes, GN04, Fusobacteria, A3DB, and unclassified phyla.

There were strong patterns in bacterial community composition along the soil depth. More specifically, the phylum Acidobacteria was dominant (52\%) at 90$120 \mathrm{~cm}$ depth, whereas its abundance was lowest (16\%) at $0-15 \mathrm{~cm}$ depth. On the other hand, Proteobacteria was dominant (39\%) at the surface soil (0-15 cm depth), but its abundance was lowest (17\%) at $90-120 \mathrm{~cm}$ depth.
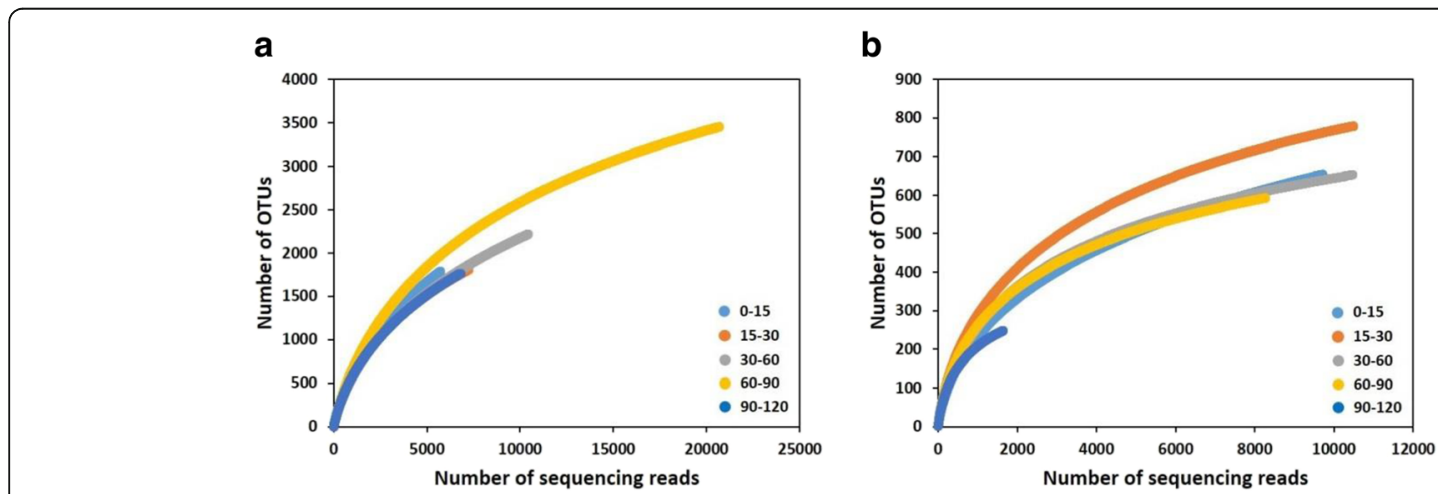

Fig. 2 Differences in rarefaction curves at $97 \%$ sequence similarity along the soil depth for a bacterial and $\mathbf{b}$ fungal communities 
Table 2 Summary of number and diversity index of microbial communities at different soil depths

\begin{tabular}{|c|c|c|c|c|c|c|c|c|c|c|}
\hline & \multicolumn{5}{|c|}{ Bacteria } & \multicolumn{5}{|l|}{ Fungi } \\
\hline & \multicolumn{5}{|c|}{ Soil depth (cm) } & \multicolumn{5}{|c|}{ Soil depth (cm) } \\
\hline & $0-15$ & $15-30$ & $30-60$ & $60-90$ & $90-120$ & $0-15$ & $15-30$ & $30-60$ & $60-90$ & $90-120$ \\
\hline Total number of sequence reads & 5735 & 7238 & 10,438 & 20,663 & 6805 & 9710 & 10,497 & 10,471 & 8261 & 1645 \\
\hline Number of OTUs (using CD-HIT) & 1789 & 1809 & 2218 & 3451 & 1765 & 654 & 779 & 653 & 593 & 249 \\
\hline Ace & 4023 & 2914 & 4428 & 4706 & 3561 & 1090 & 982 & 807 & 739 & 325 \\
\hline Chaol & 3190 & 2785 & 3442 & 4810 & 2776 & 908 & 979 & 814 & 762 & 311 \\
\hline JackKnife & 4844 & 3466 & 4205 & 6940 & 3398 & 1030 & 1106 & 861 & 6694 & 330 \\
\hline Shannon & 6.8 & 6.7 & 6.7 & 7.2 & 6.7 & 4.5 & 5.1 & 4.8 & 4.9 & 4.5 \\
\hline Simpson & 0.003 & 0.003 & 0.003 & 0.002 & 0.002 & 0.039 & 0.017 & 0.032 & 0.030 & 0.036 \\
\hline
\end{tabular}

The Actinobacteria was dominant (16\%) at the 60$90 \mathrm{~cm}$ depth but its abundance was lowest (4\%) at the 90-120 cm depth. Chloroflexi was relatively evenly distributed along the depths, ranging from 7.0 to $9.2 \%$, but it was higher in the interspace soils (30-90 cm depth). Firmicutes richness decreased along the soil depths (Figs. 3a and 4a). At the finer taxonomic scales, the most abundant bacterial class included Solibacteres and Acidobacteria_c for the phylum Acidobacteria. Abundance of the classes within Proteobacteria showed a tendency to decline along the soil depths, and this was observed for alpha, beta, delta, and gamma classes. In addition, the abundance of Clostridia, Bacilli, and Erysipelotrichi, classes of Firmicutes, decreased along the soil depths (Fig. 5a).

The abundance of major bacterial groups was significantly correlated with soil physicochemical characteristics and enzyme activity. More specifically, the abundance of Proteobacteria was positively correlated with total soil $\mathrm{C}$ concentration $(r=0.92, p<0.01), \mathrm{N}$ concentration $(r=0.86, p<0.01)$, and soil $\mathrm{pH}(r=0.57$, $p<0.05)$. It was also positively correlated with the activity of all five soil enzymes $(r>0.92, p<0.01)$. The abundance of Firmicutes was also positively correlated with total soil C concentration ( $r=0.73, p<0.01)$, N concentration $(r=0.89, p<0.01)$, and the activity of all five soil enzymes $(r>0.69, p<0.01)$. On the other hand, the abundance of Acidobacteria was negatively correlated with total soil $\mathrm{C}$ concentration $(r=-0.61, p<0.05)$ and $\mathrm{N}$ concentration $(r=-0.66, p<0.01)$. In addition, it was negatively correlated with the activity of all five soil enzymes $(-0.65<r<-0.61, p<0.05)$. The abundance of Chloroflexi was also negatively correlated with total soil C concentration $(r=-0.56, p<0.05), \mathrm{N}$ concentration $(r=-0.57, p<0.05)$, soil moisture content $(r=-0.99$, $p<0.01)$, and the activity of acid phosphatase $(r=-0.57$, $p<0.05)$ and $\beta-1,4$-xylosidase $(r=-0.53, p<0.05)$.

In the bacterial dendrogram (Figs. $4 a$ and $5 \mathrm{a}$ ), the soils of interspace $(15-90 \mathrm{~cm})$ harbored bacterial communities with $97 \%$ similarity and they were differentiated from the top $(0-15 \mathrm{~cm})$ and deepest soil $(90-120 \mathrm{~cm})$ at similarity levels of 97 and $96 \%$, respectively. The bacterial communities of $15-30$ and $30-60 \mathrm{~cm}$ soil depths formed clusters, and they showed a similarity of $98 \%$. To further examine differences of bacterial communities between soil depths, principal coordinates analysis was performed with diversity estimate indices, and all five depths were separated from each other (Fig. 6a).

The 38,546 sequences classified below the domain level were affiliated to 13 fungal phyla. In comparison to the abundance of bacterial groups such as Proteobacteria and Firmicutes that declined along the soil depth and Acidobacteria and Nitrospirae that increased along the soil depth, fungal communities showed less clear trend in their composition along the soil profile. The fungal phyla that existed across all samples were Ascomycota, Basidiomycota, Mortierellales, Fungi_uc, and Glomeromycota, and their abundance was 56, 27, 6, 5, and 3\%, respectively, of all the sequences assigned to the domain Fungi (Fig. 3b). The members of rare phyla (less than $1 \%$ of all classified ITS sequences) included Endogonales, Blastocladiomycota, Monoblepharidomycota, Entomophthoromycota, Cryptomycota, and Olpidiaceae. The abundance of phylum Ascomycota was highest (71\%) in the interspace soils (30-60 cm depth) but that of Basidiomycota was lowest (8\%) at this depth (Fig. 4b). At the finer taxonomic scales, the most abundant fungal class included Sordariomycetes for phylum Ascomycota and Agaricomycetes within Basidiomycota. The abundance of the classes Sordariomycetes and Tremellomycetes of Ascomycota and Basidiomycota showed a tendency to decrease with soil depth, while the class Eurotiomycetes of Ascomycota increased with soil depth (Fig. 5b).

The abundance of major fungal groups was significantly correlated with soil $\mathrm{pH}$ and moisture, but not with enzyme activity. For example, the abundance of Basidiomycota was positively correlated with soil $\mathrm{pH}$ 

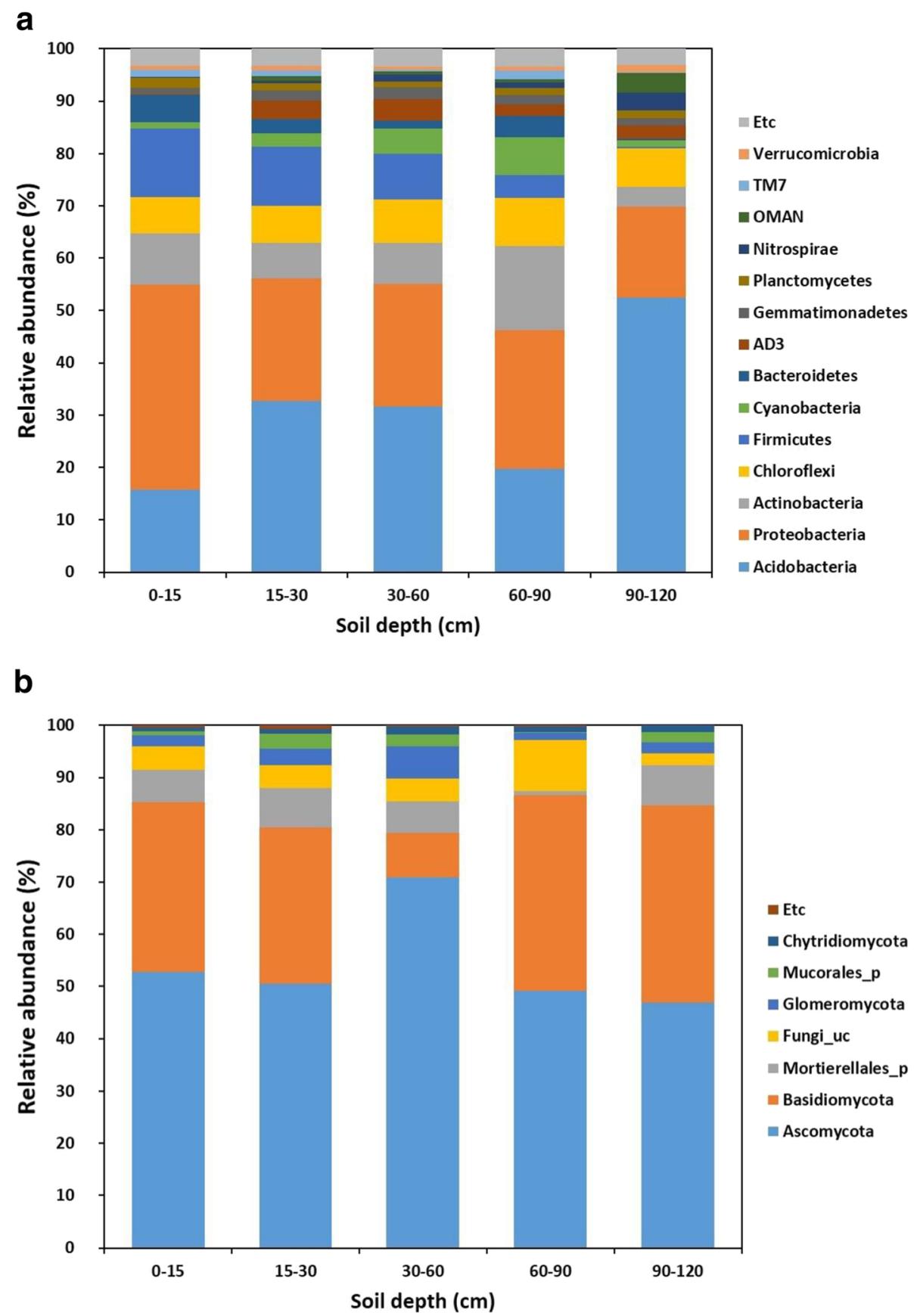

Fig. 3 Relative read abundance of the $\mathbf{a}$ bacterial and $\mathbf{b}$ fungal phyla at five different soil depths. Sequences unable to be classified into any known group were assigned to "Etc"

$(r=0.65, p<0.01)$. In addition, the abundance of Mortierellales was positively correlated with soil moisture $(r=0.85, p<0.01)$. On the other hand, the abundance of Fungi_uc was negatively correlated with soil moisture $(r=-0.75, p<0.01)$.

In the fungal dendrogram (Figs. $4 \mathrm{~b}$ and $5 \mathrm{~b}$ ), the soils of surface depths $(0-30 \mathrm{~cm})$ harbored fungal communities with $97 \%$ similarity and they formed a cluster. This cluster was differentiated from the fungal communities of $30-60,60-90$, and $90-120 \mathrm{~cm}$ soil depths. Unlike the PCoA result of bacterial communities, fungal communities at different soil depths were separated into three groups. More specifically, fungal communities of $0-15,15-30,30-60 \mathrm{~cm}$ soil depths were clustered while those of $60-90 \mathrm{~cm}$ and 90 $120 \mathrm{~cm}$ depths were separated (Fig. 6b). 
a
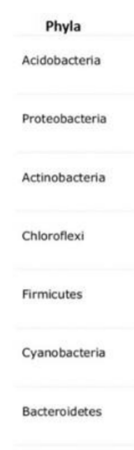

$A D 3$

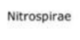

OMAN b
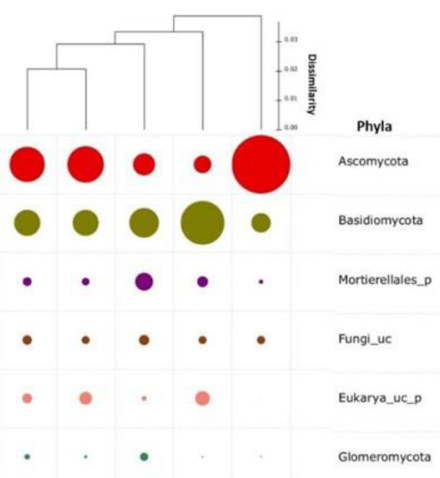

$\cdot$

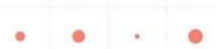

-
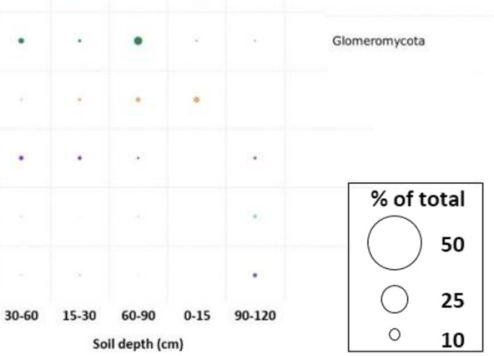

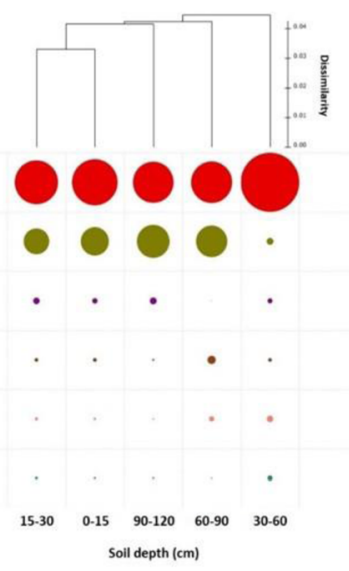

Soll depth (cm)

Fig. 4 Similarity of phylogenetic diversity at the phylum level (75\% sequence similarity) for a bacterial and $\mathbf{b}$ fungal communities. The hierarchical relationship was obtained via the unweighted pair group method with arithmetic mean (UPGMA) clustering dendrogram

\section{Discussion}

Soil enzyme activity decreased with soil depth, and this is consistent with the decrease in total $\mathrm{C}$ and $\mathrm{N}$ concentrations (Table 1). There were significant differences in soil enzyme activities along the soil depth, and the soils with highest enzyme activity were 40 - to 300 -fold higher than soils with the lowest activity (Fig. 1). High concentrations of total $\mathrm{C}$ and $\mathrm{N}$ in the topsoil $(0-15 \mathrm{~cm})$ is likely to account for this pattern observed for soil enzyme activities (Stursova and Baldrian 2011); all five soil enzymes analyzed were positively correlated with soil $\mathrm{C}$ and $\mathrm{N}$ contents. Moreover, the observed changes in microbial activity through the soil profiles parallel those reported in another study (Baldrian et al. 2012). The previous study has documented that the activities of several enzymes hydrolyzing cellulose, hemicellulose, and chitin were significantly higher in the topsoil $(1-4 \mathrm{~cm}$ thick litter horizon, ranging from $5.3 \pm 2.2$ to $\left.26.5 \pm 10.4 \mu \mathrm{mol} \mathrm{g}^{-1} \mathrm{~min}^{-1}\right)$. In comparison to forest ecosystem studies, the soils in our study site have very low concentrations of organic matter, but the trend observed is similar. In addition, positive correlation was found between the activity of enzymes that degrade organic phosphate molecules, cellulose, and chitin and soil $\mathrm{pH}$, and this was also the case with these enzymes and soil moisture content; these results suggest that soil physicochemical characteristics that change at different soil depths determine soil enzyme activity.

The observed changes in the abundances of bacterial groups were consistent with the differences in $\mathrm{C}$ availability, which indicates that $\mathrm{C}$ availability to soil microorganisms shapes microbial communities. Among soil bacterial taxa, the abundance of specific groups including Acidobacteria, $\beta$-Proteobacteria, and Bacteroidetes has been known to be significantly correlated with organic $\mathrm{C}$ availability to microorganisms and $\mathrm{C}$ mineralization rate. For example, a study conducted on soils collected from 71 sites within diverse ecosystems of North America found that as $\mathrm{C}$ mineralization rates increased, the abundance of Acidobacteria decreased, whereas the abundances of $\beta$-Proteobacteria and Bacteroidetes increased significantly (Fierer et al. 2007). In addition, other studies have reported that Acidobacteria were less abundant but $\beta$-Proteobacteria were more abundant in organic carbon-rich soils (McCaig et al. 1999, Axelrood et al. 2002, Fierer et al. 2007). Similar trends were found in our study: the abundance of Acidobacteria was negatively correlated with soil $\mathrm{C}$ concentration while that of $\beta$-Proteobacteria was positively correlated with soil $\mathrm{C}$ concentration. These results suggest that along with soil enzyme activity, the composition of bacterial communities is largely determined by $\mathrm{C}$ availability in soils.

The diversity of soil fungal communities was considerably lower than that of bacterial communities in this study (Table 2). In addition, there was no clear change in fungal community composition along the soil depth, whereas bacterial communities showed a distinct pattern across different soil depths. In the fallow field we studied, bacterial communities were more diverse and 
a

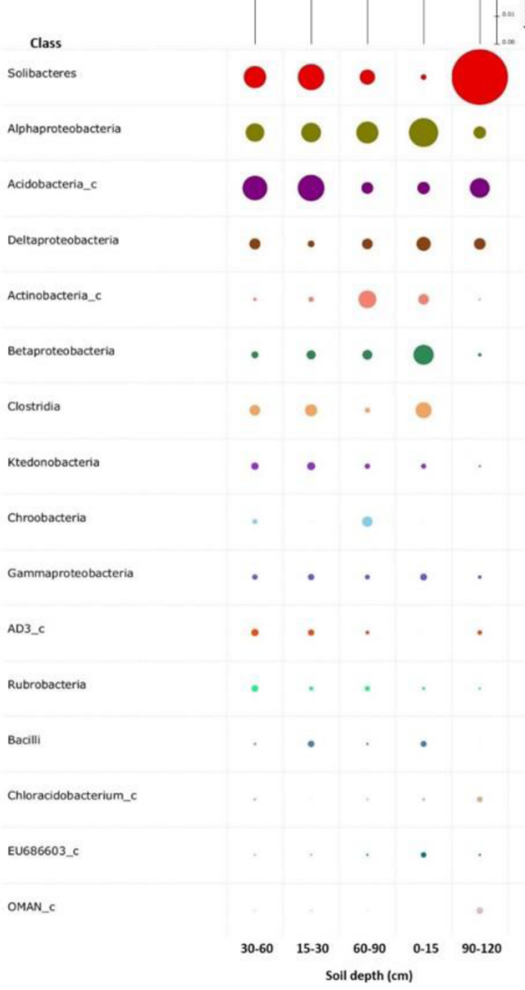

b

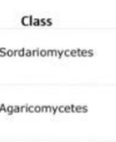

Leotionycetes

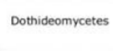

Tremellomycetes

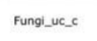

Mortierellales_c

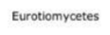

Eukarya_uc_c

Glomeromycetes

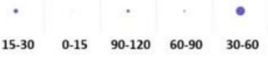

Soll depth $(\mathrm{cm})$

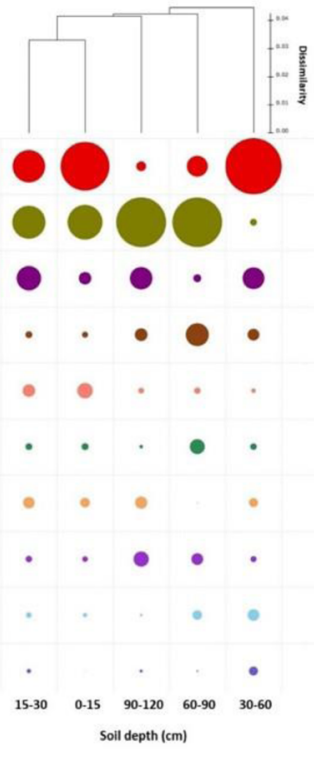

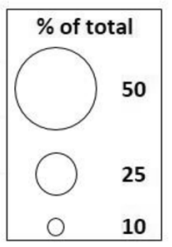

Fig. 5 Similarity of phylogenetic diversity at the class level (80\% sequence similarity) for a bacterial and $\mathbf{b}$ fungal communities. The hierarchical relationship was obtained using the unweighted pair group method with arithmetic mean (UPGMA) clustering dendrogram

mediate $\mathrm{C}, \mathrm{N}$, and $\mathrm{P}$ cycling. Fungi are expected to be more abundant in forest ecosystems where recalcitrant substrates are abundant because they play key roles in decomposition of recalcitrant matter including lignin and cellulose (Aislabie and Deslippe 2013). Therefore, it is likely that the nature of our field site accounts for the higher diversity and stronger pattern along the soil depth of bacterial communities.
Within the fungal community, Ascomycota was most abundant and this was followed by Basidiomycota (Fig. 3b). Ascomycota are known as the largest fungal phylum, and most of them are saprotrophic and have a wide variety of enzymes that degrade recalcitrant substrates such as cellulose, keratin, and lignin; consequently, Ascomycota play critical roles in nutrient cycling in soil ecosystems (Aislabie and Deslippe 2013). The Basidiomycota are the second a

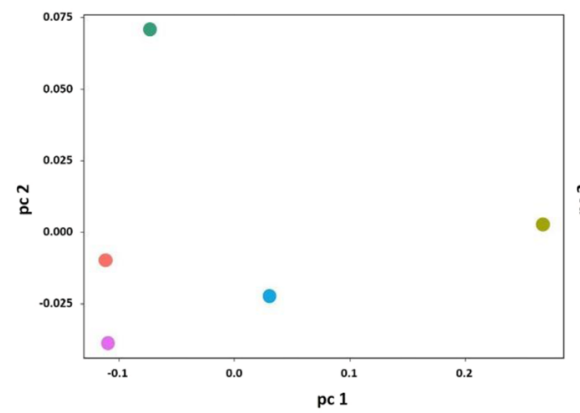

b

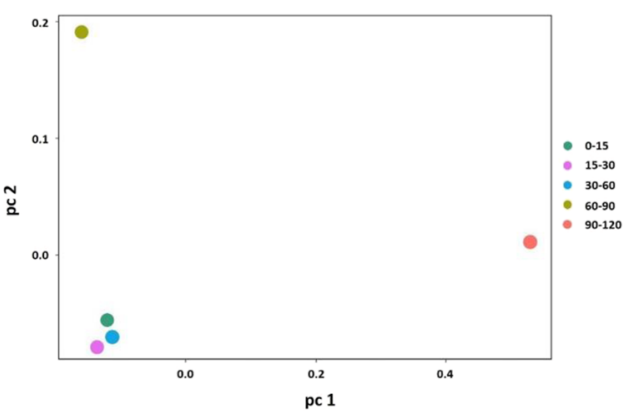

Fig. 6 Principal coordinates analysis (PCOA) of $\mathbf{a}$ bacterial and $\mathbf{b}$ fungal communities using the diversity estimate indices 
largest fungal phylum, and they are commonly known as spore-forming on the basidia during sexual reproduction and also produce mushrooms. Moreover, others are important decomposers; the families of rot fungi, such as "soft," "brown," and "white," produce peroxide and enzymes to degrade recalcitrant plant compounds including cellulose and lignin (Aislabie and Deslippe 2013). The dominance of two fungal groups found in our study site reflect that reported in other soil ecosystems. The PCoA results showed that the bacterial communities were distinct at each soil depth, whereas fungal communities of $0-60 \mathrm{~cm}$ soil depth were clustered (Fig. 6). These results are consistent with the analyses of bacterial and fungal communities at the phylum and class level (Figs. 3, 4, and 5).

\section{Conclusions}

Our study shows that soil microbial community composition and function, determined by pyrosequencing and soil enzyme analyses, are distinct at different soil depths and this was more prominent for bacterial communities than for fungal communities. Soil $\mathrm{C}$ concentration that indicates the substrate availability for microorganisms is likely to be a major factor that accounts for soil enzyme activity and microbial community composition at this site. Metagenomics study like ours, along with other studies on microbial functions, is expected to further our understanding regarding the function and composition of soil microbial communities at different soil depths.

\section{Abbreviations}

ITS: Internal transcribed spacer; OTU: Operational taxonomic units; PCoA: Principal coordinates analysis

\section{Acknowledgements}

Not applicable.

\section{Funding}

This work is supported by the Korea Ministry of Environment (MOE) as the "Korea- $\mathrm{CO}_{2}$ Storage Environmental Management (K-COSEM) Research Program (Project No. 2014001810002)."

\section{Availability of data and materials}

All data generated during this study are available from the corresponding author upon reasonable request.

\section{Authors' contributions}

DK conducted the enzyme assay, analyzed the enzyme assay and pyrosequencing data, and wrote parts of the manuscript. GY guided the field work and provided data on the soil characteristics. SY and SJ selected the study site and guided the field survey. HC designed this study and wrote parts of the manuscript. All authors read and approved the final manuscript.

\section{Ethics approval and consent to participate}

Not applicable.

\section{Consent for publication}

Not applicable.

\section{Competing interests}

The authors declare that they have no competing interests.

\section{Author details}

${ }^{1}$ Department of Environmental Engineering, Konkuk University, Seoul 05029, South Korea. ${ }^{2}$ Department of Environmental Science and Environmental Engineering, Kyung Hee University, Seoul, Gyeonggi-do 17104, South Korea. ${ }^{3}$ Department of Earth and Environmental Sciences, Korea University, Seoul 02841, South Korea. ${ }^{4}$ GeoGreen 21 Co. Ltd., Seoul 08376, South Korea.

Received: 24 May 2017 Accepted: 7 September 2017

Published online: 19 September 2017

\section{References}

Agnelli, A., Ascher, J., Corti, G., Ceccherini, M. T., Nannipieri, P., \& Pietramellara, G. (2004). Distribution of microbial communities in a forest soil profile investigated by microbial biomass, soil respiration and DGGE of total and extracellular DNA. Soil Biology and Biochemistry, 36, 859-868.

Aislabie, J., \& Deslippe, J. R. (2013). Soil microbes and their contribution to soil services. In J. R. Dymond (Ed.), Ecosystem services in New Zealand: Conditions and trends (pp. 143-161). Lincoln: Manaaki Whenua Press.

Axelrood, P. E., Chow, M. L., Radomski, C. C., McDermott, J. M., \& Davies, J. (2002). Molecular characterization of bacterial diversity from British Columbia forest soils subjected to disturbance. Canadian Journal of Microbiology, 48, 655-674.

Baldrian, P., Kolarik, M., Stursova, M., Kopecky, J., Valaskova, V., Vetrovsky, T., Zifcakova, L., Snajdr, J., Ridl, J., Vlcek, C., \& Voriskova, J. (2012). Active and total microbial communities in forest soil are largely different and highly stratified during decomposition. ISME Journal, 6, 248-258.

Blume, E., Bischoff, M., Reichert, J. M., Moorman, T., Konopka, A., \& Turco, R. F. (2002). Surface and subsurface microbial biomass, community structure and metabolic activity as a function of soil depth and season. Applied Soil Ecology, 20, 171-181.

Buss, H. L., Bruns, M. A., Schultz, M. J., Moore, J., Mathur, C. F., \& Brantley, S. L. (2005). The coupling of biological iron cycling and mineral weathering during saprolite formation, Luquillo Mountains, Puerto Rico. Geobiology, 3, 247-260.

Chun, J., Kim, K. Y., Lee, J. H., \& Choi, Y. (2010). The analysis of oral microbial communities of wild-type and toll-like receptor 2-deficient mice using a 454 GS FLX titanium pyrosequencer. BMC Microbiology, 10, 101.

Eilers, K. G., Debenport, S., Anderson, S., \& Fierer, N. (2012). Digging deeper to find unique microbial communities: the strong effect of depth on the structure of bacterial and archaeal communities in soil. Soil Biology and Biochemistry, 50, 58-65.

Fierer, N., Schimel, J. P., \& Holden, P. A. (2003). Variations in microbial community composition through two soil depth profiles. Soil Biology and Biochemistry, 35, 167-176.

Fierer, N., Jackson, J. A., Vilgalys, R., \& Jackson, R. B. (2005). Assessment of soil microbial community structure by use of taxon-specific quantitative PCR assays. Applied and Environmental Microbiology, 71, 4117-4120.

Fierer, N., Bradford, M. A., \& Jackson, R. B. (2007). Toward an ecological classification of soil bacteria. Ecology, 88, 1354-1364.

Goberna, M., Insam, H., Klammer, S., Pascual, J. A., \& Sanchez, J. (2005). Microbial community structure at different depths in disturbed and undisturbed semiarid mediterranean forest soils. Microbial Ecology, 50, 315-326.

Hamady, M., Lozupone, C., \& Knight, R. (2010). Fast UniFrac: facilitating high-throughput phylogenetic analyses of microbial communities including analysis of pyrosequencing and PhyloChip data. ISME Journal, 4, 17-27.

Hansel, C., Fendorf, S., Jardine, P., \& Francis, C. (2008). Changes in bacterial and archaeal community structure and functional diversity along a geochemically variable soil profile. Applied and Environmental Microbiology, 74, 1620-1633.

Huber, T., Faulkner, G., \& Hugenholtz, P. (2004). Bellerophon: a program to detect chimeric sequences in multiple sequence alignments. Bioinformatics, 20, 2317-2319.

Hur, M., Kim, Y., Song, H. R., Kim, J. M., Choi, Y. I., \& Yi, H. (2011). Effect of genetically modified poplars on soil microbial communities during the phytoremediation of waste mine tailings. Applied and Environmental Microbiology, 77, 7611-7619.

Kim, B. S., Kim, J. N., Yoon, S. H., Chun, J., \& Cerniglia, C. E. (2012a). Impact of enrofloxacin on the human intestinal microbiota revealed by comparative molecular analysis. Anaerobe, 18, 310-320.

Kim, O. S., Cho, Y. J., Lee, K., Yoon, S. H., Kim, M., Na, H., Park, S. C., Jeon, Y. S., Lee, J. H., Yi, H., Won, S., \& Chun, J. (2012b). Introducing Eztaxon-e: a prokaryotic $16 \mathrm{~S}$ rRNA gene sequence database with phylotypes that 
represent uncultured species. International Journal of Systematic and Evolutionary Microbiology, 62, 716-721.

LaMontagne, M., Schimel, J., \& Holden, P. (2003). Comparison of subsurface and surface soil bacterial communities in California grassland as assessed by terminal restriction fragment length polymorphisms of PCR-amplified 165 rRNA genes. Microbial Ecology, 46, 216-227.

McCaig, A. E., Glover, L. A., \& Prosser, J. I. (1999). Molecular analysis of bacterial community structure and diversity in unimproved and improved upland grass pastures. Applied and Environmental Microbiology, 65, 1721-1730.

Nannipieri, P., Ascher, J., Ceccherini, M. T., Landi, L., Pietramellara, G., \& Renella, G. (2003). Microbial diversity and soil functions. European Journal of Soil Science, $54,655-670$.

Rumpel, C., \& Kogel-Knabner, I. (2011). Deep soil organic matter-a key but poorly understood component of terrestrial C cycle. Plant and Soil, 338, 143-158.

Saiya-Cork, K. R., Sinsabaugh, R. L. \& Zak, D. R. (2002). The effects of long term nitrogen deposition on extracellular enzyme activity in an Acer saccharum forest soil. Soil Biology and Biochemistry, 34, 1309-1315.

Sengupta, A., \& Dick, W. A. (2015). Bacterial community diversity in soil under two tillage practices as determined by pyrosequencing. Microbial Ecology, 70, 853-859.

Stursova, M., \& Baldrian, P. (2011). Effects of soil properties and management on the activity of soil organic matter transforming enzymes and the quantification of soil-bound and free activity. Plant and Soil, 338, 99-110.

Trumbore, S. (2000). Age of soil organic matter and soil respiration: Radiocarbon constraints on belowground C dynamics. Ecological Applications, 10, 399-411.

Will, C., Thurmer, A., Wollherr, A., Nacke, H., Herold, N., Schrumpf, M., Gutknecht, J., Wubet, T., Buscot, F., \& Daniel, R. (2010). Horizon-specific bacterial community composition of German grassland soils, as revealed by pyrosequencingbased analysis of 165 rRNA genes. Applied and Environmental Microbiology, $76,6751-6759$

Xu, X., Thornton, P. E., \& Post, W. M. (2013). A global analysis of soil microbial biomass carbon, nitrogen and phosphorus in terrestrial ecosystems. Global Ecology and Biogeography, 22, 737-749.

\section{Submit your next manuscript to BioMed Central and we will help you at every step:}

- We accept pre-submission inquiries

- Our selector tool helps you to find the most relevant journal

- We provide round the clock customer support

- Convenient online submission

- Thorough peer review

- Inclusion in PubMed and all major indexing services

- Maximum visibility for your research

Submit your manuscript at www.biomedcentral.com/submit

) Biomed Central 